\title{
SOME SEA DEFENCE WORKS IN ENGLAND
}

$$
\text { C. H. DOBBIE }
$$

Consulting Engineor

Westminster, Lonảon, S.W.I.

The tidal flood of Jon.-Pob. 1953, which coused much damage to the east and south-east coasts of Ingland, was investigated by numerous Authorities, including the Government Waverley Comrittee.(1) The report of this last body has resulted in further alterations of methods of financing sea defence works. A fundamental alteration in the basio conception for design of sea walls has also taken place. Instead of attompting to build to extreme hoights to exclude tidal flooding, it is now usual to allow for a certain degree of overtopping during top flood conditions. The systems of legislation, administration and finance, now brought up to modern standards, are set out with some reference to their histories. Pactors af focting design heights of sea walls are enumerated. type of revetment developed in Bngland, and much used in the works constructed following the floods is described.

\section{ADIIINISTRATION OF SFA DFPFNCES}

Sea defence work, inevitably a community onterpriae, can only be carried out before a background of proper legislation and adminitration. The background has interest and importance in itself, naturally, but to engineers employed in coastal work it is more likely to be regarded as a means to an ond. In Fingland and Wales sea defence administration is now divided between two groups of Local Authorities under the general supervision of two Government Departments. The first group consists of Drainage Authorities for low lying, reclaimed lands who have always protected their shores. Some of these Drainage Authorities are of great antiquity. The second group consists of Municipal, Urban and Rural Authorities whose activities on the coast are much more recent.

Originally the Draingge Authorities were rooted in a seni-feudal comrunity whose lifo wes almost entirely looal in character. As conditions slowly changed, so did the Drainage Authorities evolve. So sure and strong were their traditions that they persisted right through the Industrial Revolution almost unchanged. Although outmoded by a contury or so they survired intact until 1930 and some until 1950. The earliest Authority recorded is that of Romey Marsh in Kent, where, in 1245, procedure could already be defined as by ancient Iaw and castom. In generel, jurisdiction of these Authorities derived from a Comrission issued by Henry III (1216-1272). Rurther Commissions followed and are traced by Dugdale.(2) A Statute of 1427 advanced their status, and in 1531 a Bill of Sewers gave permanence to their being and remained the basis of all legislation until 1930. 
Although the powers conferred by statute were vague and ill defined, the importance of the tasks fulfilled by the Commissioners led them to assume very real authority with or without genuine legal brisis. The lorger estates, as the greatest payers of soots or rates, obviously had ruch influence in determining policy and usually a constructive outlook was accepted as part of their heritage. These estates were represented by agents or bajllifs who joined the tenant furmers to form the Drainage Boards or Commissions. Wuch good wo rir was done, especially with clay walls. As oarly as Henry VII (1485-1509) Romnoy Warsh was installing groynes. Works were inspected on foot by the Comrission at regular intervals, and the inspoction was followed by a dinner where grievances were settled. Jidney lebb (3) in his monumental studies of Local Government has traced the origin of the Lordon County Council to a Commission administering the marshes adjoining the Thames. The Commissions adapted themselves to the slow changes of rural life, but when new ways of life rapidly followed the opening up of communioations and the vast expansion of industry, their basic, archaic, and very local structure beoame a handicap in attempting to cope with now finances and with technical developments. In 1930, by the Land Drainage Aot, Catohment Boards were sot up prinai pally for arterial land drainage. These new Boards carried out many sea defence works. By the Biver Board Aot of 1948 the whole of Bngland wos covered by a number of River Boards, new omibus Authorities responsible for see defenoes of low lying lands, for land drainage and for pollution of rivers. This is again a step forward, although there is an early tendency to exaggerate in importance the somewhat negative subjoot of river pollution as against the highly tochnical and edministratively untidy subject of sea defonce, colling as it does for uncossing positive action and unpredictable expenditure.

The second group of Authorities comprises mainly the seaside towns. These towns have grom up rapidly in the last 200 years. Their origin was the coincidence of popularity of sea bathing with the great extension of transport facilities; but they are now often complete towns with industries. Over the years they oarried out many sea defonce works, especially for soa front promenades, and usually derived their spooifle jurisdiction by locel Acts of Parliament. By the Coast Protection Act of 1949 their powers were codified and oxtendod. Those difflcult lengths where the town overlapped the promonade wero also brought in. The erontages of many Urban Districts and Rural Districts, usually alif Prontages presenting many oconomio problems, were also inoluded.

It wos fortunate that the legislation had been straightened out before the disastrous tidal surge of January 3ist - Bebruary 1 st, 1953 , brought havoe to the coast. It was, of course, unfortunate that the affected Authorities had not acquired groater experience, but at least they existed, and were ablo to expand and not entirely improvise to moet the oatastrophe. Bollowing this disaster, the Waverley Comnitteo was set up by the Government to enquire into the evont. One result of their report has been the final oquating of the financial arrangements between 
the Government and oach group of Authorities.

The position is now that Local Authoritios of either kind can borrow money to oarty out oepital works and can receive grants in aid from the Government up to $85 \%$. For maintenance works they may receive up to $50 \%$ grant from the Government. This last ooncession is of the greatest importance. It was provided for the second Authority group in the Coast Protection Act, but had in practice not been applied before the 1953 flood. It now applies to all Authorities and is likely to be much used and to ensure great benofits to soa defence works whore, more than anywhere elso, "a stitoh in time saves nine" or even ninety.

It is often argued that the state should take over the whole and administor directly, but it is indicative of tomperament that the only known oountries to do this are Russia and Germany. A complox changing coastline is best handled in daily works and emorgencios by those who live with it, although they may from time to time dorivo woh benefit from out side tochnioal skill. Tho old adage that "He who pays the piper ool is the tune" is still the basis of Locel Government finance, so to have local ontrol and responsibility the basis mast be by local paying. Authorities of the firat group wero purposely made largo enough to have considerablo finances. For the second group the prinoiple of locel payment is taken through a logical sequence, with provision for dividing the costs amongst frontager interests, the Town or District and the County Counoil. If the burden is too great the Government grants aro availablo. Theoretio2lly these could make the Government Departments dominant in oalling the tune, but in practice they have refrained noticoably from doing so.

\section{THE HEIGHT OP SEA WALLS}

The protection of low lying land is almost invariably a wall of clay dug from adjacent land. Until the Plood of 1953, the basic prinolple of construction was to make these ol ay walls so high that thoy could nevor be overtopped. Thoy had to be to a height not less than the top lovel of the highest tide, with a further allowance for wave action. Sol level is affeoted by the astronomioal or prodictable tide, by storm surges, by variations in barometric pressure, and by the offoots of local winds. It is also affected by long term relative movements of land and soa, oustatio and isostatio. Above the mean sea level are the waves and their projection or swash on meeting doa walls. Above this again is a zone of splash and spray.

The very groat height of sea level caused by the surge of 1953 has caused ongineers to alter the basic concoption that the walls should novor be overtopped.(4) The idoa now acoepted in Ingland, as in Holland, is that under excoptional oircumatances walls may suffer a degree of overtopping, and must be designed to pass over this top water without breaching and collapse. This now idoa has brought with it many now problems. As an instance, there is a strong controversy as to whether 
olay out off from rainfall by a completely impervious wall oovering, front, top and back, would or would not dry out to an extent dangerous to the strength of the wall.

The long term pioture is not holpful, as it appoars that in the south and south-east, where wach of the sea defence works are concentrated, there is a sinking of land relative to the sea at a rate of one foot per 100 years, whilst in the north-west and Sootland, where there are fer defence woriks, the land is rising from the sea. In the Waverley report it is stated: "Since the evidenoe is entirely consistent in pointing to a sinking of the southeast and rise of North Britain it is olear that some of the movement is differential and so confined to the land. This differential beheriour can be explained by the movement resulting from two different factors. On the one hand a tilt of the land is most reasonably to be explai ned by the slow recovery from the great weight of 1 co which covered so much of Britain and north-weatern Burope in the Quaternary Period; on the other hand the general rise of seo level is due to the progressive melting of the polar (land) $i 0 \theta$, and the shrinkage of glaoiers, which has increased the water in the oceans as whole." This factor. is of the greatest importanoe as the main feature of the immediate past soulpturing the coastline of Eingland has not been so much contemporary erosion and accretion but rather the ahanges of sea level. Godwin at Cambridge by pollon analysis of peat deposits has tracod my such changes in glacial and post glacial times. (5) The present tendencies have been plotted by valentine. (6)

The next and imediate factor is the question of storm surges which are fromen: to oocur, not only in the North Sea, affecting the ooast, but also in the Pnglish Channel, the Bristol Channel and the Irish Sea affeoting the south and west cossts. These are now being studied in some detail.

\section{A SRA WALL REVGTMMAT}

\section{CONCRBHE BLOCKS WITH ASHALTIC JOINT \$}

A short paper of this nature is of necessity ealeotio in subject, and for construction a revetment has been chosen of a type originated and developed in Ingland during the last 16 years. It has been desoribed in various papers by the author. $(7,8,9,10)$. In this present paper, American praotice of desoribing the product from the oil refinery as asphalt is followed. In England it is called bitumen and asphalt is reserved for the mixture of bitumen filler and graded sand and/or stone comronly used in road work.

The seal walls, already described as being of local olay or silt, rest on foundations of the same materials, sometimes with sub-layers of almost serdi-liquid mad, and often with layers or pockets of peat. On suoh foundations the wall mass must sink gradually and in uneven degreo. 
This factor mast be considered in deaigning the revetments wich protect the walls frorn wave action. The revetment itself must have sufficient Plexibility to settle with the well resting properly on it, and yot maintaining protection agsinst waves. The classical method of handpitched stones on a broken stone bed has become inordinately expensive, and there is a shortage of skilled men. A method originated by Essex Rivers Catchment Board some 16 years ago is to lay pre-cast conorete blocks direotly on the olay surface, and to grout the joints with a hot mixture of asphalt, sand and asbestios fibre. The blocks are made and cured under factory conditions to give a strong dense conorete resistant to selt water action and to abrasion. The jointing is selected, proportloned, mixed and hoated to give a material inert in salt water which is elastio to shook pressures but plastic to the slow settlement of the wall and the blooks. Bven at the highest summer temperatures it does not flow down the wall. The properties of the jointing are not dependent upon adhesion to the blocks, but in the provision of a plastio elastio filler that keeps the revetment surface sealed, and prevents the blocks being moved by direct impact or by pressure effects.

After trying various shapes, including hexagons, blocks are invariably made square in plan. The size of square and the thickness vary with exposure and with desingers' ideas. Blooks in ourrent use range from 70 lbs. In weight to 1700 lbs. No failures, no displacements of blooks by wares have been reported. The only maintenanoe has been some hot ironing and making up of joints. One bay $30 \mathrm{ft}$. by $30 \mathrm{ft}$. has sunk unevenly to form a basin of maximum depth $2 \mathrm{ft}$., without breaking the surfaco. On the lst oheok the area of this type of revetment laid was 500,000 square yards, but it is likely now to be about 1,000,000 square yards.

\section{REFERTANCES}

(1) Beport of the Departmental Cormittee on Dostal Mooding. Her Majesty's Stationery Office 1954.

(2) W. Dugdale (1605-1685) History of Imbanking and Drainage. and Fd. Owen \& Urial, London 1772.

(3) S. Wobb. English Looal Government Statutory Authoritios for Spocial Furposes. Longman. Vol.I.

(4) Conference on the North Sea Floods.

The Instn. of Civil Engineers. 1954.

(5) J.A. Steers. The Coastine of Rigland and Walos. Cambridge Univoraity Press. 1946.

(6) H. Valontino. Prosent Vertioal lovemonta of British Isles. Geog. Jounr. $119(3)$ Sopt. 1953.

(7) C.H. Dobbie. Some Soa Dofenoe Worirs for Reolatmed Lands. J.Instn. Civil Engineors Vol.25 (1945-46) and corrospondence. 
(8) G.H. Dobbie. \& E.J.R. Konnerell, Uso of Bitumen in Hydroulio Works. J.Instn. Civil Engrineers. Vol.33 (1949-50)

(9) C.H. Dobbie. Protective works adopted to limit erosion al ong the open ooast, etc. CI SII Inst. Nav.Cong. Lisbon 1949.

(10) C.H. Dobbio. New designs of broakwaters, otc.

QI SII XVIII Int. Nav. Cong. Rome 1953.

\section{RESUME}

QUELQUES IRAVAUX DE DEFENSE DES COTES EN ANGLE TERRE

$$
\text { C. H. Dobbie }
$$

Le raz de marée de la Mer du Nord du 31 Janvier au ler Février 1953 , déjà décrit dans une communioation d'un auteur hollandais, a causé de grands dommages en Angleterre. Plus de 300 personnes ont été noyées et l'inondation a atteint 24.000 maisons, plus de 200 propriétés industrielles importantes et 160.000 ares de terrains agricoles. La catastrophe donna une grande impulsion à l'étude des problèmes de défense contre la mer. Un Comité d'enquête, prési dé par Lord Waverley, fut constitué par le gouvernement et l'Institution des Ingénieurs oivils se réunit en un congrès spécial où 12 rapports furent présentés et discutés. Dans le cadre de la présente communication il est possible d'indiquer seulement une interprétation éleotrique des nombreux aspects des problèmes qui furent soulevés: trois d'entre eur sont retenus parce qu'ils caractérisent l'évolution récente de la teohnique et des idées générales. Nos exemples concernent les dispositions administratives générales, les relations entre le niveau de la mer et les projets des digues et les progrès dans un type partioulier de revetement.

En Angleterre, une longue tradition a conduit à confier entièrement la défense oontre la mer aux autorités locales, divisées en deux groupes. Un groupe assure la défense des terrains bas, analogues aux polders de Hollande. Quelques-uns de ces groupes remontent à une haute antiquite. L'un d'eux, ayant des références remontant à l'an 1245, était dé jà bien organisé au XIIIo siècle. Ces autorités, habituellement à faibles effectifs, gardèrent en grande partie leur organisation légale et financière inchangée jusqu'à 1930, quand les commissions de captage des eaux furent instituées. En 1949 un nouveau changement survint lorsque la fusion et I'extension des commissions de captage des eaux se traduisirent par la création des oommissions des rivières oouvrant le territoire tout entier.

I'autre groupe est d'origine plus moderne et comprend les Conseils municipaux et régionaux dont 'les aotivités englobent souvent la défense oontre la mer et les soins d'aménagement des plages do bains de mer et les promenades de bord de mer.

Excepté par le moyen d'actes locaux, les autorités n'avaient auoun pouvoir légal spécifique dan les défenses contre la mer jusqu'à ce que I'ensemble de la question flut régularisé par le décret de protection des côtes en 1947. 
On doit reoonnaitre que les deux groupes étaient à peine installés dans leur Mouvelies Ionotions lorsque la catastrophe s'abattit sür èx. Cet évènement eut au moing une oonséquence houreuse: pour la première fois, leurs responsabilités furent clairement définies. Ces changements eurent pour résultat de valoir le conoours finanoier de I'Etat aux deux groupes, sous la forme de subventions. A la suite du rapport du Comité Waverley, de nouveaux remaniements ont été faits et les deux groupes purent obtenir dos subventions couvrant jusqu'à $85 \%$ des dépenses pour les travaux d'équipement ot jusqu'a $50 \%$ pour les travaux d'entretien. Dans les régions basses, les dépensos corrospondantes sont couvertes sur les crédits alimentés par dos taxos localos de drainage, des taxos prélevéos sur l'ansemble dos régions de captage des eaux et par lo Trésor publio. Pour d'autres dépenses, les crédits proviennent des contributions des propriétaires qui tirent un bénéfice spécial des taxes générales locales, des taxes du comité et des subventions du Trésor public. Par cos moyens, le principe de la responsabilité locale est conservé, mai il se oombino avec une répartition des lourdos charges entre des communautés d'un territoire plus étendu.

La protection des terres bassos so fait habituellement au moyen des digues d'argilo extraito sur place. Jusqu'aux dernières inondations, lo principe général était de les oonstruire assez heutes pour qu'elles no soient pas submorgéos. C'est pourquoi leur hauteur devait être au moins égalo au plus haut niveau de la marée, compte tenu de l'action des vagues. Le niveau de la marée hauto est affecté par la marée astronomique, par les raz de maréo, par los variations de la pression atmosphérique ot les variations dues au vent locel ot par les mouvements à longue période enstem tiques et iso-statiques. A oes niveaux stables se superposent l'élévation des vagues et les projections contre les digues. Plus haut encore ost une zone d'éclaboussements et d'embruns.

L'énorme élévation du ras de marée de 1953 a obligé de remettre en question ces principes et les projets s'orientent maintenant sur la base d'une tolérance à degré limité de submersion. Cette nouvelle oonoeption a posé de nouveaux problèmos, dont quelquos-uns n'ont pas reçu de solution.

Les digues reposent habituollement sur des fondations très préoaires, souvent sur de l'humus, on sorto que le besoin se fait sentir d'un revetement ayant un haut degré de flexibilité, capable de s'ajuster étroitoment a la masso de la digue et cependant do continuor à fournir uno proteotion contro l'gotion dos vaguos.

Dans lo sud de l'Angloterre, un revêtoment de blocs de béton avec des joints bituminoux a été réalisé avoc un grand succès. Il est d'un prix de premier établissoment raisonnablo, et très économique d'ontretion. Uno surface jusqu'à $500.000 \mathrm{sq.yards}$ a été dès.à présent mise en place. 